\title{
Description of eight new species of the traumatically inseminating plant bug genus Coridromius (Heteroptera: Miridae: Orthotylinae: Coridromini)
}

\author{
Nikolai J. TATARNIC ${ }^{1,3,4}$ and Gerasimos CASSIS ${ }^{2,3}$ \\ ${ }^{3}$ Evolution \& Ecology Research Centre, University of New South Wales, Sydney NSW 2052, Australia. \\ ${ }^{4}$ Department of Biological Sciences, Macquarie University, Sydney NSW 2109, Australia. \\ Corresponding author e-mail: nikolai.tatarnic@mq.edu.au \\ ${ }^{1}$ urn:lsid:zoobank.org:author:D4E32316-C080-473C-BE6A-4FC8DCB752FC \\ ${ }^{2}$ urn:lsid:zoobank.org:author:498B4DAD-B2BF-445E-8654-1A9969AE62E2
}

\begin{abstract}
Eight new species of the plant bug genus Coridromius are described: C. basilanus sp. nov. from the Philippines, C. eremnos sp. nov. from Sabah, Malaysia, C. fomangsu sp. nov. and C. tafo sp. nov. from Ghana, $C$. norfolkensis sp. nov. from Norfolk Island, Australia, $C$. mulu sp. nov. from Sarawak, Malaysia, C. macchabeeus sp. nov. from Mauritius, and C. taravao sp. nov. from Tahiti, French Polynesia.
\end{abstract}

Key words. Miridae, plant bug, Coridromini, new species.

Tatarnic N.J. \& Cassis G. 2013. Description of eight new species of the traumatically inseminating plant bug genus Coridromius (Heteroptera: Miridae: Orthotylinae: Coridromini). European Journal of Taxonomy 35: 1-24. http:// dx.doi.org/10.5852/ejt.2013.35

\section{Introduction}

The plant bug genus Coridromius Signoret, 1862 (Heteroptera: Miridae) has a paleotropical distribution, and is found from West Africa to the tropical islands of the Pacific, with one species recently introduced to the Americas (Tatarnic \& Cassis 2008; Carpintero \& Guarda 2011). Coridromius is unique among the Miridae in that all species mate via traumatic insemination, whereby males use their hypodermic intromittent organ (formed by coupling of the left paramere with the aedeagus as in bed bugs - see Carayon 1966) to stab females in the abdomen during mating, completely bypassing the female genitalia (Tatarnic et al. 2006). Presumably in response to the costs associated with traumatic insemination (for discussion of related costs in bed bugs, see Morrow \& Arnqvist 2003; Reinhardt et al. 2003; SivaJothy 2006), females of several species have evolved paragenital structures at the site of insemination (Tatarnic et al. 2006; Tatarnic \& Cassis 2008; Tatarnic \& Cassis 2010), analogous to the ectospermalege and mesospermalege of bedbugs (Carayon 1966).

First described by Montrouzier (1861) under the name Ocypus, Coridromius has always been problematic taxonomically. Initially placed in the tribe Orthotylini Van Duzee, 1916 (Schuh 1974; Linnavuori 1994), Coridromius was more recently moved to the Halticini (Cassis \& Gross 1995; Schuh 1975), presumably 
based on the lack of interramal lobes on the posterior wall of the female genitalia (the authors did not explicitly justify their decision, though a lack of interramal lobes was said by Schuh (1974) to always distinguish the Halticini). Following a phylogenetic analysis and revision of the Halticini Costa, 1853 (Tatarnic \& Cassis, 2012), Coridromius has since been removed from this tribe to form its own monogeneric tribe, the Coridromini Tatarnic \& Cassis, 2012.

Some of the newly presented species are described from single specimens. While such descriptions are generally to be avoided, we are confident in our assessment, based on the characters we have documented and our deep knowledge of the genus (we have collectively looked at virtually every museum specimen of Coridromius, and have described or redescribed every known species: see Tatarnic \& Cassis 2008).

\section{Material and Methods}

This paper reports five new species discovered in existing museum collections as well as three new species (Coridromius mulu sp. nov., C. norfolkensis sp. nov., C. taravao sp. nov.) discovered through recent collecting efforts. Species descriptions and terminological usage follow Tatarnic \& Cassis (2008). Acronyms AI through AIV refer to antennal segments. All examined specimens are labelled with matrix code labels, providing each specimen with a "unique specimen identifier" (USI). These USI codes include a project code followed by a unique eight-digit number (e.g., UNSW_ENT 00000028 is the USI for the holotype of C. taravao sp. nov.). USI codes are listed in the specimens examined, which also include all available collection data as provided on labels, such as collector, date, host plant data, and georeferencing information. All specimen information has been entered into the Planetary Biodiversity Inventory plant bug database (https://research.amnh.org/pbi/), and is available to the public via Discover Life (www.discoverlife.org) and Heteroptera Species Pages (http://research.amnh.org/pbi/ heteropteraspeciespage).

All measurements are in millimetres. Because the hemelytra in Coridromius are strongly declivent at the base of the cuneus, the total body length is recorded as the distance from the clypeus to the cuneal fracture. Habitus images were taken using a Visionary Digital system equipped with an Infinity PhotoOptical K-2, 3-lens system and a Canon EOS 40D digital camera (www.visionarydigital.com). Images presented are derived from multiple photographs, concatenated using Helicon focus (www.heliconsoft.

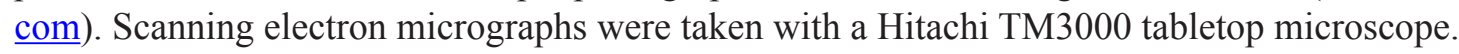

Institutional depositories and their acronyms are as follows:

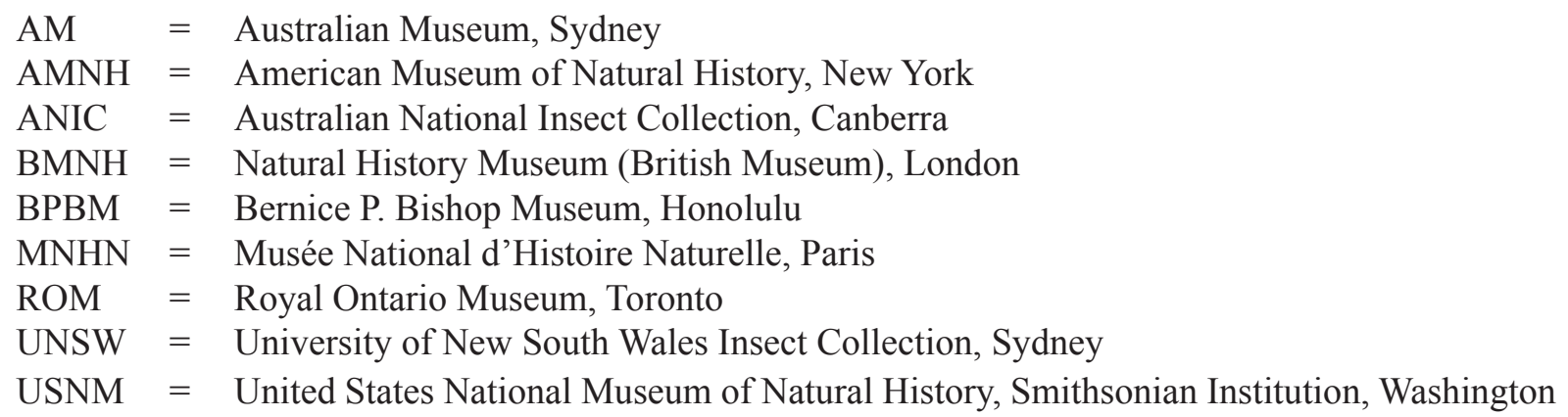




\section{Results}

Phylum Arthropoda Latreille, 1829

Class Insecta Linnaeus, 1758

Order Hemiptera Linnaeus, 1758

Suborder Heteroptera Latreille, 1810

Family Miridae Hahn, 1831

Subfamily Orthotylinae Van Duzee, 1916

Tribe Coridromini Tatarnic \& Cassis, 2012

Coridromius basilanus sp. nov.

Fig. 1A-E

urn:Isid:zoobank.org:act:301CD34B-E7FF-4C7B-B9C8-5DF36CCF5B63

\section{Diagnosis}

Most similar to $C$. declivipennis Tatarnic \& Cassis, 2008 but distinguished by the shape of the ventral apical process of the pygophore, which is reduced to a truncate, rounded tumescence (versus a broad rounded lobe in C. declivipennis: see Tatarnic \& Cassis 2008: Fig. 11).

\section{Etymology}

Named for the type locality.

\section{Type material}

\section{Holotype}

${ }^{\lambda}$, PHILIPPINES: Basilan Island (Island of Basilan Baker), $6.58^{\circ} \mathrm{N}-122.04^{\circ} \mathrm{E}$, date and collector unknown (AMNH_PBI 00191429)(USNM).

\section{Description}

BoDy LENGTH. $\overbrace{}^{\Uparrow}$ (holotype): $1.97 \mathrm{~mm}$.

Colouration (Fig. 1A-B). Mostly pale orange-brown with yellow and dark brown markings. Head: Mostly brown. Frons with faint yellow vittae. Paired swellings adjacent to eyes yellow, ocular margins and posterior margin of head yellow, clypeus, mandibular and maxillary plates yellow. Buccula brown basally, becoming yellow, labrum brown, labium yellow, brown apically. Antennae: AI dark brown with yellow at apices, AII mostly pale orange-brown with apical 1/4 slightly darker, subapically with faint narrow white annulation, AIII and AIV orange-brown, white basally. Thorax: Pronotal collar yellow. Pronotum mostly orange-brown with faint yellow midline, lateral and posterior margins. Mesoscutum orange-brown. Scutellum orange-brown, with darkened puntures and faint yellow facia along midline, apex and lateral margins. Processes of proepimeron yellow. Thoracic pleura brown, posterior margins yellowed. Hemelytra: Mostly orange-brown, slightly paler along claval commissure. Membrane pale brown with slightly darker veins. Abdomen: Orange-brown. Legs: Fore- and midlegs orange-brown. Hindlegs missing from specimen.

Surface And vestiture (Fig. 1A-D). Head, pronotum, scutellum, and hemelytra shallowly punctate. Head and body clothed in white, decumbent, hairlike setae.

HEAD. Approximately $6.6 \mathrm{x}$ as wide as eye in anterior view. Frons medially tumescent. Vertex with two minor swellings adjacent to eyes, bordered posteriorly by two shallow depressions. Posterior margin of head weakly carinate, rounded in anterior view (Fig. 1A). 
THorax. Pronotum rounded and steep, posterior margin weakly concave, lateral and posterior margins weakly carinate, anterolateral margins somewhat depressed, not upturned, submarginal region of humeral angles weakly excavate, calli weakly defined (Fig. 1A-C). Proepimeron bilobed (Fig. 1C-D). Posterior margin of metepimeron truncate (Fig. 1C). Scutellum weakly tumescent and flat, with midline, apical and lateral fascia (Fig. 1B).
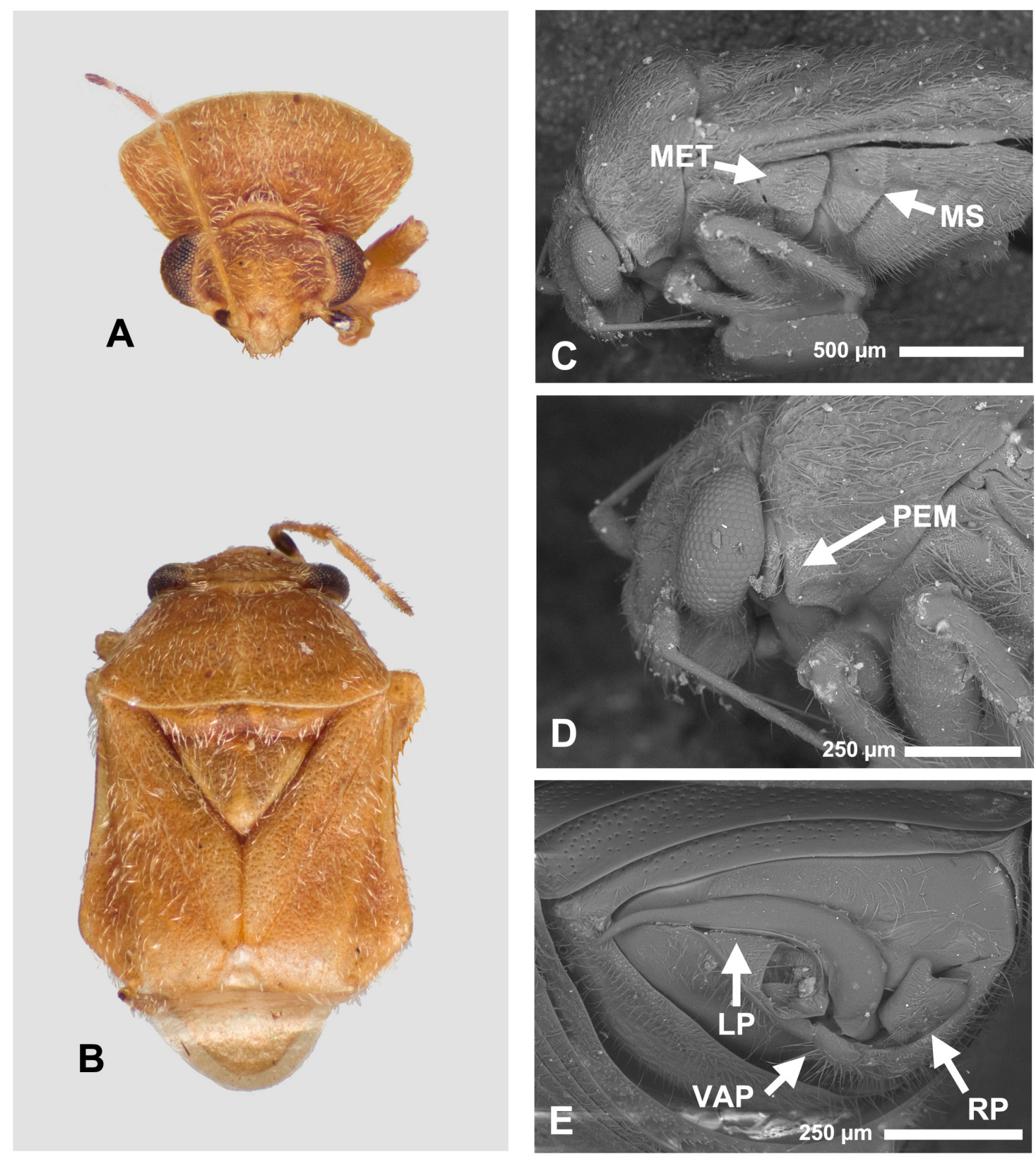

Fig. 1. Photographs and scanning electron micrographs of Coridromius basilanus sp. nov. A. Head and pronotum, anterior view. B. Dorsal habitus. C. Lateral view. D. Head and prothorax, lateral view. E. $O^{\lambda}$ genitalia. $\mathrm{LP}=$ left paramere, $\mathrm{MET}=$ metepimeron, $\mathrm{MS}=$ mesal sulcus, $\mathrm{PEM}=$ proepimeron, $\mathrm{RP}=$ right paramere, $\mathrm{VAP}=$ ventral apical process of pygophore 
HeMELYTRA. Costal margin weakly concave, flared outwards at apex (Fig. B).

LEGS. Metafemora missing from specimen.

ABDOMEN. Posterolateral margin of abdominal sternite II sharply angled, with transverse medial sulcus (Fig. 1C).

MALE GENitALIA. Right paramere broad and rounded with thumblike lobe on inner margin. Left paramere heavily sclerotized, elongate ( $\sim 4 \mathrm{x}$ length of right paramere), basally thickened and sharply angled, with midsection relatively straight, apex slightly curved and overhanging margin of pygophore, gutter housing aedeagus nearly enclosed to apex (Fig. 1E). Pygophore with elongate mesal longitudinal suture, ventral apical process reduced to a rounded tumescence (Fig. 1E).

Female paragenitalia. Unknown.

\section{Host}

Unknown.

\section{Distribution}

Basilan Island, Philippines.

\section{Remarks}

This is the third species to be described from the Philippines, the others being C. ephippius Tatarnic \& Cassis, 2008 and C. marmoreus Tatarnic \& Cassis, 2008. The characteristic flaring of the hemelytron distinguishes $C$. basilanus sp. nov. from its Philippine congeners, as does its predominantly pale orangebrown colouration (C. marmoreus is distinctly speckled in colour, while C. ephippius is considerably darker, with AII apically brown). Coridromius basilanus sp. nov. appears most similar to C. declivipennis, which is known only from Okinawa, Japan (Tatarnic \& Cassis 2008).

\section{Coridromius eremnos sp. nov.}

Fig. 2A-B

urn:lsid:zoobank.org:act:648C3E10-2191-4855-86C6-7C378496F567

\section{Diagnosis}

Recognized by the following combination of characters: body uniformly black with pale silvery hairlike setae; head black with yellow margins; antennae banded dark brown and pale yellow; proepimeron bilobed.

\section{Etymology}

Named for the Greek eremnos, meaning black.

\section{Type material}

\section{Holotype}

q, MALAYSIA: Sabah, beaches 2 km NW of Kuala Penyu, 10 Aug. 1983, G. F. Hevel and W. E. Steiner (AMNH_PBI 00191199) (USNM).

\section{Description}

BODY LENGTH. ? (holotype): $1.68 \mathrm{~mm}$. 

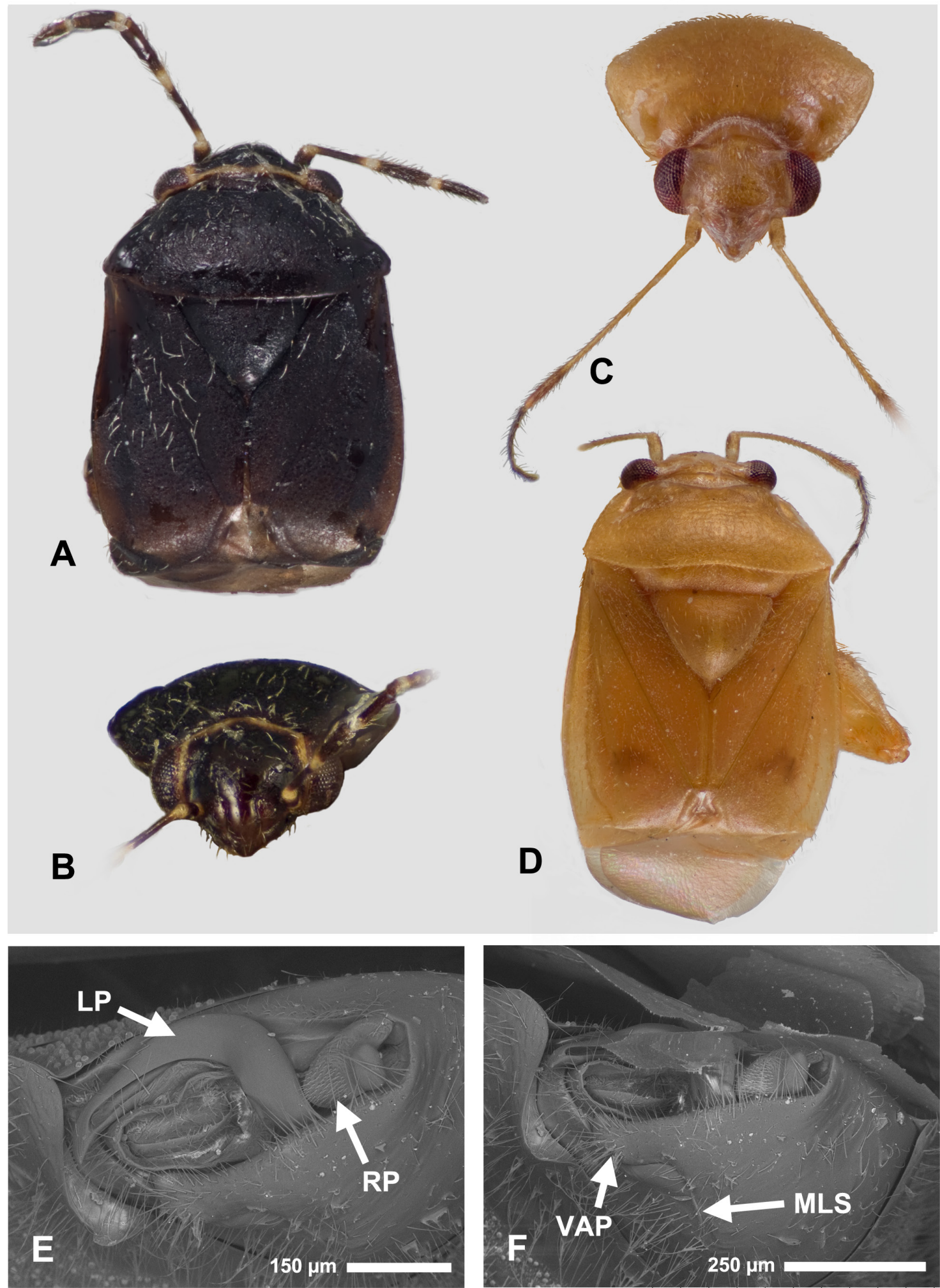

Fig. 2. Photographs and scanning electron micrographs of Coridromius eremnos sp. nov. and C. fomangsu sp. nov. - A-B. Coridromius eremnos sp. nov. A. Dorsal habitus. B. Head and pronotum, anterior view. - C-F. Coridromius fomangsu sp. nov. C. Head and pronotum, anterior view. D. Dorsal habitus. E. Male genitalia, posterior view. F. Male genitalia, posteroventral view. LP = left paramere, MLS = mesal longitudinal suture of pygophore, $\mathrm{RP}=$ right paramere, $\mathrm{VAP}=$ ventral apical process of pygophore. 
Colouration (Fig. 2A-B). Almost entirely dark brown/black, with some white and pale yellow markings. Head: Black with pale yellow trim along inner ocular margin and posterior margin (Fig. 2A-B). Labium with first segment dark brown, the remainder orange-yellow. Antennae: AI dark brown with white apices, AII dark brown with narrow white medial annulation, AIII and AIV dark brown with white basal annulation (Fig. 2A). Thorax: Pronotal collar, pronotum, mesoscutum and scutellum uniform dark brown/black (Fig. 2A). Thoracic pleura dark brown/black. Anterior proepimeral lobe white, posterior lobe black. Evaporative area of metathoracic scent gland orange-yellow. Hemelytra: Uniform dark brown/black, membrane brown with dark brown veins. Abdomen: Dark brown/black. Legs: Pro- and mesofemora dark brown with apical $1 / 4$ orange-yellow, pro- and mesotibia orange-yellow with faint brown subbasal annulations, metatibia and metafemur uniform dark brown, metafemur without transverse banding. All tarsi yellow with claws brown.

SuRface and vestiture (Fig. 2A-B). Head, pronotum, thoracic pleura, scutellum, and hemelytra impunctate. Body clothed in long, white, decumbent setae [most setae knocked off the specimen].

HEAD. Approximately $5.6 \mathrm{x}$ as wide as eye in anterior view (Fig. 2B). Frons strongly medially tumescent, merging with two minor swellings adjacent to eyes. Posterior margin of head rounded, weakly carinate. Antennae shorter and stouter than in other species, with AII slightly less than width of head (AII $>$ than head width in others) (Fig. 2A).

Thorax. Pronotum broad and steep, posterior margin weakly convex, lateral and posterior margins weakly carinate, submarginal region of humeral angles excavate, calli obsolete (Fig. 2A). Proepimeron bilobed. Posterior margin of metepimeron truncate. Scutellum tumid (Fig. 2A).

HemelytRA. Margins of embolium weakly flared towards cuneus (Fig. 2A).

LEGS. Metatibial spines prominent.

AвDOMEN. Posterolateral margin of abdominal sternite II angular, weakly carinate and slightly flared.

MaLE Genitalia. Unknown.

Female Paragenitalia. No obvious paragenital structures visible.

\section{Host}

No host plant data.

\section{Distribution}

Known only from Sabah.

\section{Remarks}

Only one other species, C. nigrus Carvalho, 1987 shares a nearly uniform black colouration. However, these species are readily separated by the proepimeron (unilobed in C. nigrus, bilobed in C. eremnos sp. nov.), and the female paragenitalia, which in C. nigrus is recognised by a well-defined swelling of the right abdominal laterotergites II and III, and the posterior margin of abdominal sternite II strongly carinate and flared to expose a putative copulatory opening. 
Coridromius fomangsu sp. nov.

Fig. 2C-F

urn:Isid:zoobank.org:act:AB15427B-747C-4941-9BA1-FC9C6C00E393

\section{Diagnosis}

Distinguished from all other species by a combination of the following features: the uniform yelloworange colouration, the unique form of the right paramere, and the callosite region with two broad swellings bordered laterally by deep sulci.

\section{Etymology}

Named after the type locality of South Fomangsu Forest Reserve.

\section{Type material}

\section{Holotype}

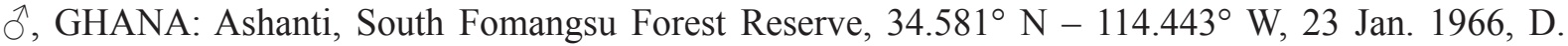
Leston (AMNH_PBI 00192741) (BMNH).

\section{Paratype}

1 ऽ, locality data same as for holotype, 23 Jan 1966, D. Leston (AMNH_PBI 00192742) (BMNH).

\section{Description}

Body Length. $\hat{\sigma}(\mathrm{n}=2): 3.30-3.57 \mathrm{~mm}$.

Colouration (Fig. 2C-D). Uniform pale yellow- to pale orange-brown. Head: Frons without vittae (Fig. 2C). Clypeus slightly embrowned, mandibular plate, maxillary plate and gena tinted red, labrum and labium pale orange brown, labium apically embrowned. Antennae: mostly pale orange-brown. AI weakly embrowned apically, clavate apex of AII weakly embrowned, AIII and AIV brown. Thorax: Uniformly pale orange-brown (Fig. 2C-D). Thoracic pleura slightly paler along trailing margins. Hemelytra: Uniformly pale orange-brown, with faint brown chevron on corium, membrane slightly paler and translucent (Fig. 2D). Legs: Uniformly pale orange-brown, metafemur without transverse brown banding. Abdomen: Uniform pale orange-brown.

Surface And vestiture (Fig. 2C-D). Mostly impunctate. Head shallowly punctuate (Fig. 2C). Scutellum medially weakly rugulose (Fig. 2D). Body with hairlike setae, setae on anterior and dorsal surface of head short and adpressed, with longer and semi-erect setae on lateral and ventral surfaces (Fig. 2C-D). Antennae clothed in semi-decumbent hairlike setae interspersed with a few more erect, thin, spinelike setae (Fig. 2C). Pronotum with sparse distribution of short, reddish-brown reclining setae, hemelytra with sparse distribution of short, pale, semi-reclining setae and shorter, reddish-brown setae. Abdomen with slightly more dense coating of longer, semi-erect setae. Femora with thick, reddish-brown, semierect setae, longer on ventral surface. Tibiae with thick, pale semi-erect, setae, metatibia with two rows of thick, caudally directed spines.

HEAD. Approximately $5.6 \mathrm{x}$ as wide as eye (Fig. 2C) in anterior view. Frons weakly tumescent, vertex with shallow transverse depressions adjacent to eyes, posterior margin broadly medially rounded, not carinate (Fig. 2C). Buccula swollen. Antennae: AII basally thin, apically clavate (Fig. 2C-D).

THORAX. Pronotum broad, collar thick and broadly triangular, callosite region with two broad swellings bordered laterally by deep sulci, lateral and posterior margins rounded, posterior margin slightly declivent (Fig. 2C-D). Proepimeron bilobed. Posterior margin of metepimeron truncate. Scutellum swollen and rounded (Fig. 2D). 
Hemelytron. Costal margin thinly carinate, weakly flared posteriorly (Fig. 2D).

AвDOMEN. Posterior margin of abdominal sternite II not distinctly angular in lateral view.

Male genitalia. Pygophore with mesal longitudinal suture elongate, right side of suture with apical apophysis lying transversely across pygophore margin (Fig. 2F). Left paramere a short, thick, angular scythe slightly twisted along its axis, right paramere cleft, with inner lobe elongate and outer lobe short and rounded (Fig. 2E).

Female Paragenitalia. Unknown.

\section{Host}

No host records.

\section{Distribution}

South Fomangsu National Park, Ghana.

\section{Remarks}

Coridromius fomangsu is one of three species now known from Ghana (the others being C. tafo sp. nov. described herein, and C. lestoni Tatarnic \& Cassis, 2008), and one of five now known from Africa. All three Ghanan species are readily distinguished by size, colouration and male genitalia. In particular, $C$. fomangsu sp. nov. is the only species in the genus with a right paramere of this form.

\section{Coridromius macchabeeus sp. nov.}

Fig. 3A-D

urn:1sid:zoobank.org:act:52DD412D-6DAB-4AA1-A938-1AF93B3DD4C3

\section{Diagnosis}

Recognised by the following combination of characters: frons nearly flat, smooth and shining, pronotum densely punctate with well-demarcated callosite region, and proepimeron unilobed.

\section{Etymology}

Named for the Macchabee Forest where the holotype was collected.

\section{Type material}

\section{Holotype}

, MAURITIUS: Macchabee Forest, $20.4^{\circ} \mathrm{S}-57.45^{\circ}$ E, 8 Jun. 1971, A. M. Hutson (AMNH_PBI 00377687) (BMNH).

\section{Description}

Body LeNGTH. $q$ (holotype): $2.32 \mathrm{~mm}$.

Colouration (Fig. 3A-B). Mostly concolorous orange-yellow. Head: Orange-yellow (Fig. 3A). Antennae mostly orange-yellow, AI with broad brown medial annulation, AII with apical club brown (Fig. 3AB), AIII and AIV brown, paler at base. Pronotum: orange-yellow with a faint green tint (Fig. 3A-B). Thoracic pleura orange-yellow. Hemelytra: Orange-yellow (Fig. 3B). Legs: Uniform orange-yellow; metafemur without transverse banding; tarsi slightly embrowned. Abdomen: Uniform orange-yellow. 
Surface And vestiture (Fig. 3A-B). Head smooth, without punctures (Fig. 3A). Head, pronotum and scutellum glossy (Fig. 3A-B). Pronotum, hemelytra, and scutellum with fine punctations (Fig. 3A-B). Thoracic pleura impunctate. Pronotum and hemelytra clothed in very short, brown, semidecumbent, spinelike setae (Fig. 3B). Buccula with brown hairlike setae. Pronotal collar with slightly longer white, decumbent hairlike setae. Legs with brown, hairlike setae. Metatibial spines short and thin.

Head. Approximately $6 \mathrm{x}$ as wide as eye (Fig. 3A) in anterior view. Frons weakly convex, nearly flat, posterior margin rounded and thin, weakly carinate (Fig. 3A-B). Bucculae tumid. Antennae thin, AII long and slender with weak apical club (Fig. 3A-B).

Thorax. Pronotum with calli deeply demarcated (Fig. 3A). Posterior margin of pronotum weakly medially cleft and thinly carinate, posteromedial margins depressed (Fig. 3B). Proepimeron appears unilobed, with reduced anterior lobe barely visible (fig 3C). Posterior margin of metepimeron truncate with sulcate groove (Fig. 3D). Scutellum rounded and swollen (Fig. 3B).

HemelytRa. With lateral margin weakly sinuate (Fig. 3B).

AвDomen. Posterolateral margin of second abdominal sternite relatively straight.
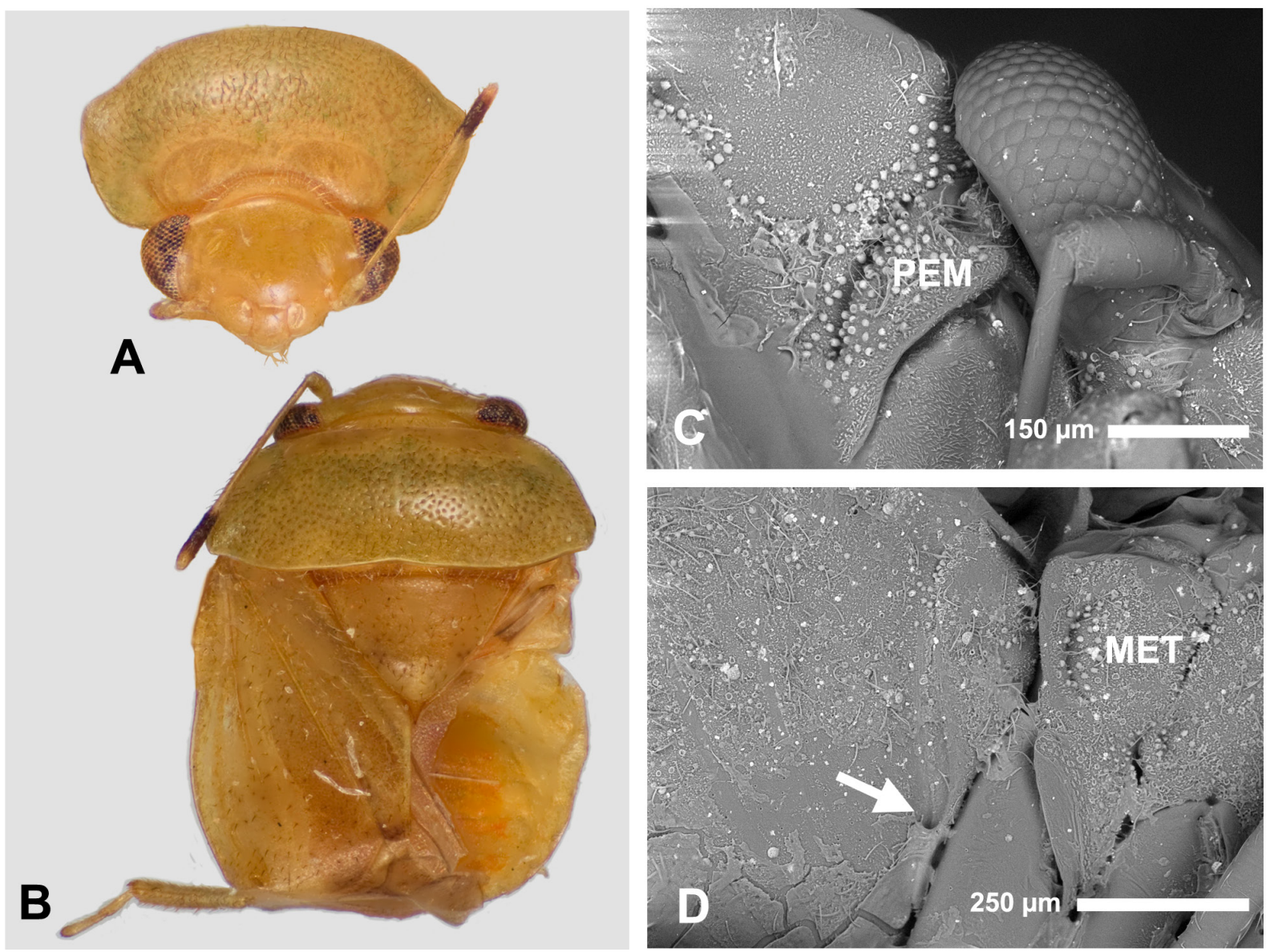

Fig. 3. Photographs and scanning electron micrographs of Coridromius macchabeeus sp. nov. A. Head and pronotum, anterior view. B. Dorsal habitus. C. Head and prothorax, lateral view. D. Metathorax and anterior of abdomen, lateral view, arrow indicates copulatory guide. $\mathrm{MET}=$ metepimeral lobe, $\mathrm{PEM}=$ proepimeron. 
MaLe Genitalia. unknown.

Female Paragenitalia. Right second abdominal sternite swollen, posterolateral margin slightly flared and carinate, exposing a copulatory groove leading to site of penetration (Fig. 3D).

\section{Host}

Unknown.

\section{Distribution}

Known only from the type locality.

\section{Remarks}

This is one of several species that have been discovered from examination of undetermined material at the Natural History Museum, London. Based on this sole specimen, we cannot comment on whether or not this species is endemic to Mauritius or has a wider distribution.

\section{Coridromius mulu sp. nov.}

Fig. 4A-G

urn:lsid:zoobank.org:act:FF4A14C9-0D8A-4EFA-ACA2-8DC0D9F677FE

\section{Diagnosis}

Recognized by the following combination of characters: pronotum, scutellum, and thoracic pleura punctate; proepimeron bilobed; mostly tan colouration with dark brown markings on hemelytron adjacent to scutellum; right paramere with thumblike process; posterior margin of pygophore with long mesal longitudinal suture and broad triangular projection; caudal margin of metepimeron inflexed and abutting anterolateral margin of abdomen; and female with right anterolateral margin of abdomen slightly swollen and desclerotized, sometimes with small melanised scars.

\section{Etymology}

Named for the national park from which it was collected.

\section{Type material}

\section{Holotype}

${ }^{\lambda}$, MALAYSIA: Sarawak, Gunung Mulu National Park, clearing near Deer cave entrance, $4.0395^{\circ} \mathrm{N}$ $-114.838^{\circ}$ E, 250 m, 12-22 Aug. 2010, N. Tatarnic and D. C. Darling, ex. Homolanthus sp. flowers (Euphorbiaceae) (UNSW_ENT 00000001) (ROM).

\section{Paratypes}

All collected 12-22 Aug. 2010 by N. Tatarnic and D. C. Darling on Homalanthus sp. flowers (Euphorbiaceae) (det. N. Tatarnic), locality data same as for holotype: 4 우 (UNSW_ENT 00000012-

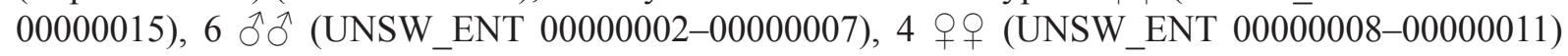
(UNSW).

\section{Description}

Body Length. $\overbrace{}^{\lambda}(\mathrm{n}=5): 1.53-1.79 \mathrm{~mm}$, $+(\mathrm{n}=5): 1.77-1.91 \mathrm{~mm}$.

Colouration (Fig. 4A-C). Mostly pale brown with yellow and dark brown markings, often with a faint green tint which fades in pinned specimens. Head: Mostly yellow-brown, frons without vittae, with faint yellowed midline, paired tumescences adjacent to eyes sometimes yellow, ocular margins 

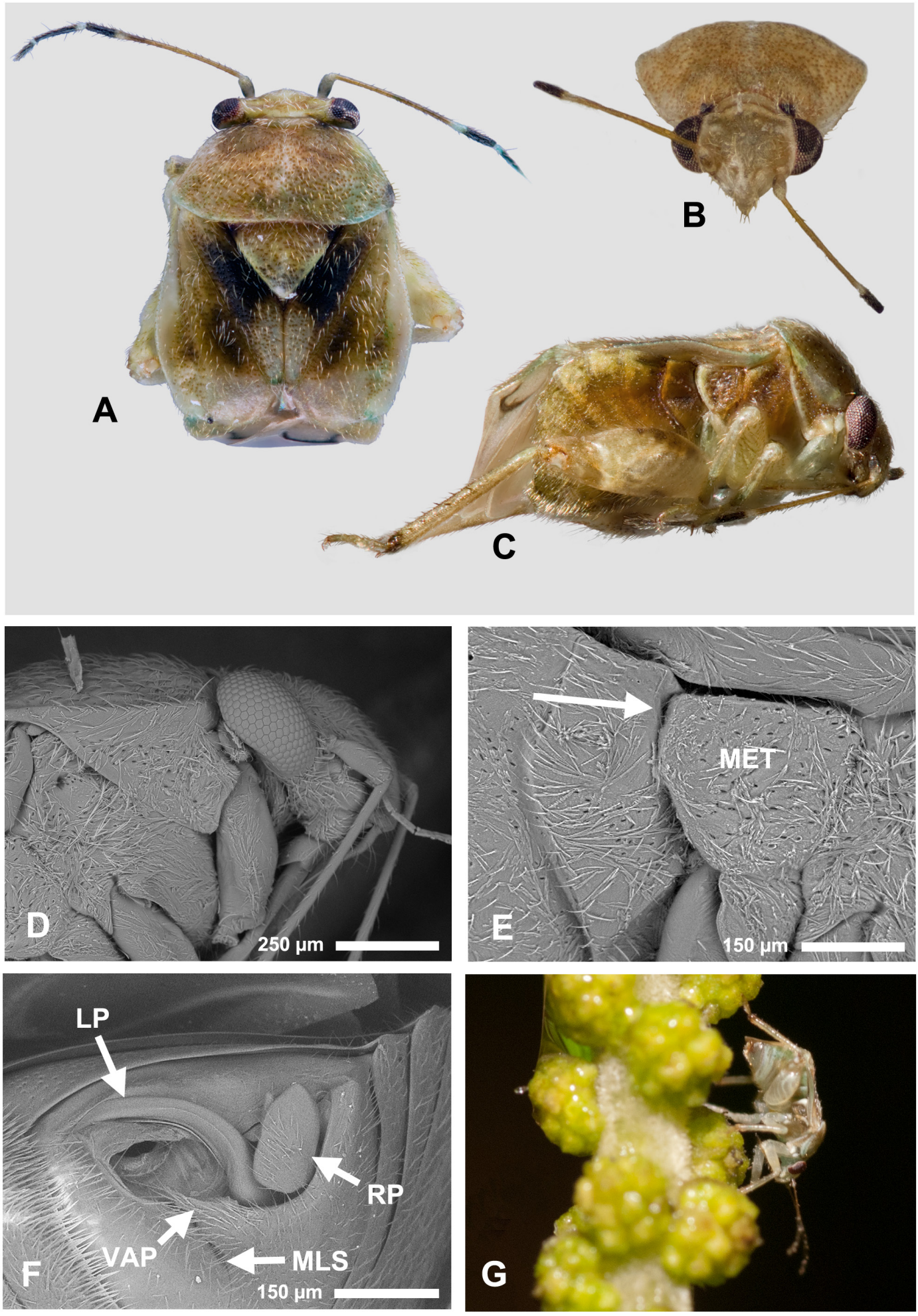

Fig. 4. Photographs and scanning electron micrographs of Coridromius mulu sp. nov. A. Dorsal habitus, $\widehat{\jmath}$. B. Head and pronotum, anterior view, $\widehat{\jmath}$. C. Lateral view, + . D. Head and thorax, lateral view. E. Metathorax and anterior of abdomen of $q$, lateral view; arrow indicates site of insemination. $\mathbf{F}$. $\hat{\delta}$ genitalia. G. Photograph of $\widehat{\partial}$ on unidentified species of Homalanthus. LP $=$ left paramere, MET $=$ metathoracic lobe, $\mathrm{MLS}=$ mesal longitudinal suture of pygophore, $\mathrm{RP}=$ right paramere, $\mathrm{VAP}=$ ventral apical process of pygophore. 
and posterior margin of head cream to yellow (Fig. 4B). Clypeus pale yellow, gena, mandibular and maxillary plates yellow, buccula pale brown basally with small darker brown marking, white along ventral margin. Labrum brown basally, white at apex. Labium white, brown apically. Antennae: AI pale yellow with broad, dark brown annulation medially, AII mostly pale orange-brown, apically dark brown, subapically with prominent narrow white annulation, sometimes slightly darker below this, AIII and AIV dark brown, white basally (Fig. 4A-C). Thorax: Pronotal collar yellowed with dark brown markings at lateral margins. Pronotum mostly orange-brown with darkened punctures and faint yellow midline, anterior margin with two small dark brown markings behind eyes, calli and humeral angles faintly darkened, yellow along lateral and caudal margins (Fig. 4A-B). Mesoscutum orange-brown with darker brown punctures. Scutellum pale to orange-brown with darkened punctures and faint white to pale yellow midline, apex and basal corners (Fig. 4A). Processes of proepimeron white, thoracic pleura orange-brown with darker brown punctures, posterior margins pale yellow to white (Fig. 4C). Hemelytra: Mostly orange-brown with dark brown punctures and yellow and dark brown markings. Clavus basally orange-brown, dark brown adjacent to scutellum, yellow to cream coloured along claval commissure, corium orange brown with broad, dark brown marking in line with claval commissure, becoming yellow toward apex, embolium yellow with orange-brown to dark brown medial marking, cuneus yellow-brown to brown, with darker brown punctures, membrane brown with dark brown veins (Fig. 4A). Abdomen: Mostly orange-brown, becoming yellowed along dorsolateral margin, segment II orange-brown (Fig. 4C). Abdomen of some specimens with faint green tint. Legs: predominantly pale cream-colored. Metafemur darker orange-brown dorsally, with faint diagonal brown stripes on outer surface, metatibia with narrow dark brown apical annulation, caudally facing spines dark orange-brown (Fig. 4C). Tibiae faintly darkened apically.

SuRfaCe AND VestituRE (Fig. 4A-F). Head, pronotum, thoracic pleura, scutellum and hemelytra punctate (Fig. 4A-E). Body clothed in long, white, decumbent setae (Fig. 4A-F). Left posterior margin of abdominal sternite VIII of male with a patch of dense, conelike setae (Fig. 4F).

HEAD. Approximately $5.8 \mathrm{x}$ as wide as eye (Fig. 4B), in anterior view. Frons medially tumescent. Vertex weakly depressed with two minor swellings adjacent to eyes (Fig. 4B). Posterior margin of head rounded, weakly carinate (Fig. 4B).

Thorax. Pronotum broad and steep, posterior margin weakly concave, lateral and posterior margins weakly carinate, submarginal region of humeral angles weakly excavate, calli weakly defined (Fig. 4A). Proepimeron bilobed (Fig. 4C-D). Posterior margin of metepimeron weakly lobed, sometimes weakly mesially deflected, trailing edge pressed against abdomen (Fig. 4E). Scutellum somewhat flattened, with midline, apical and lateral fascia (Fig. 4A).

HemelytRa. Costal margin convex, subapically flared (Fig. 4A).

Legs. Metatibial spines prominent (Fig. 4C).

AвDOMEN. Posterolateral margin of abdominal sternite II sharply angular and weakly carinate, anterior abdominal margin deflected inwards (Fig. 4E).

Male Genitalia. Right paramere broad and rounded with thumblike lobe on medial margin (Fig. 4F). Left paramere heavily sclerotized, main body weakly curved, sharply angled basally, apex laterally compressed, gutter nearly enclosed to apex (Fig. 4F). Pygophore with elongate mesal longitudinal suture terminating in a triangular ventral apical process (Fig. 4F).

Female Paragenitalia. Right dorsal laterotergite II (first visible segment) slightly swollen, with faint depression immediately adjacent to metepimeral lobe, thought to guide male paramere (Fig. 4E). 


\section{Host}

Collected from the male flowers of an unidentified species of Homalanthus (Euphorbiaceae) (Fig. 4G).

\section{Distribution}

Collected outside Deer Cave in Gulung Mulu National Park, Sarawak, Malaysia.

\section{Remarks}

This species was found exclusively on the male flowers of its host plant, an unidentified species of Homalanthus. Coridromius mulu sp. nov. is one of seven species now known from Borneo, most of which are known from a single locality. In this species the site of insemination in females (at the anterior margin of the abdomen) is sometimes marked with small melanised scars. Internal paragenital structures have yet to be examined in this species.

\section{Coridromius norfolkensis sp. nov. \\ Fig. 5A-F \\ urn:1sid:zoobank.org:act:3F1ACB4B-898C-4FBE-A127-C784B598FECD}

\section{Diagnosis}

Recognized by the following combination of characters: anterolateral margins of hemelytra strongly projecting laterally; proepimeron unilobed; posterior margin of metepimeron angled inward and abutting the anterior margin of the abdomen.

\section{Etymology}

This name was chosen to reflect the species' endemic distribution on Norfolk Island.

\section{Type material}

\section{Holotype}

O, AUSTRALIA: Norfolk Island, Ball Bay, end of Marsh Road, 29.04816 ${ }^{\circ} \mathrm{S}-167.98024^{\circ} \mathrm{E}, 69 \mathrm{~m}$, 22 Apr. 2011, N. Tatarnic \& A. Namyatova, ex. Schinus terebinthifolius Raddi, 1820 (Anacardiaceae) (AMNH_PBI 00019666) (AM).

\section{Paratypes}

AUSTRALIA: Norfolk Island, Ball Bay, end of Marsh Road, 29.04816 ${ }^{\circ} \mathrm{S} 167.98024^{\circ} \mathrm{E}, 69 \mathrm{~m}, 22 \mathrm{Apr}$. 2011, N. Tatarnic \& A. Namyatova, Schinus terebinthifolius (Anacardiaceae), 10 $\widehat{\jmath}$ (UNSW_ENT 00019667-00019676), 2 우 (UNSW_ENT 00019677-00019678) (AM), Schinus terebinthifolius

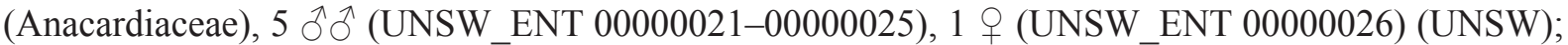
Norfolk Island National Park, Mt Bates, $29.01^{\circ} \mathrm{S}-167.56^{\circ}$ E, 300 m, 07 Apr. 1984, E. D. Edwards, 1

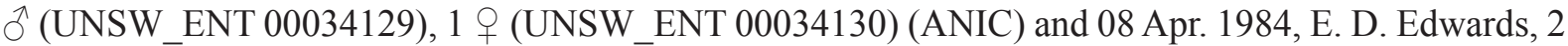

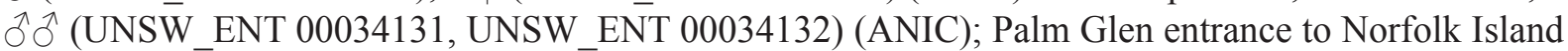
National Park, $29.02503^{\circ} \mathrm{S}-167.95194^{\circ}$ E, 129 m, 20-21 Apr. 2011, N. Tatarnic \& A. Namyatova, Schinus terebinthifolius (Anacardiaceae), 3 $\widehat{\jmath}$ (UNSW_ENT 00000017-00000019), 1 (UNSW_ ENT 00000020) (UNSW); Corner of Prince Phillip Dr and Red Rd, 29.01804 ${ }^{\circ} \mathrm{S}-167.95795^{\circ} \mathrm{E}$, 186 m, 22 Apr. 2011, N. Tatarnic \& A. Namyatova, Schinus terebinthifolius (Anacardiaceae), 2 ऽ $\delta^{\Uparrow}$ (UNSW_ENT 00046008-00046009), 1 ㅇ (UNSW_ENT 00046010) (BPBM), Schinus terebinthifolius (Anacardiaceae), 1 गे (UNSW_ENT 00000027) (UNSW).

\section{Description}

Body LENGTH. $\widehat{O}(\mathrm{n}=5): 1.84-2.04 \mathrm{~mm}$, $q(\mathrm{n}=5): 1.89-2.01 \mathrm{~mm}$. 

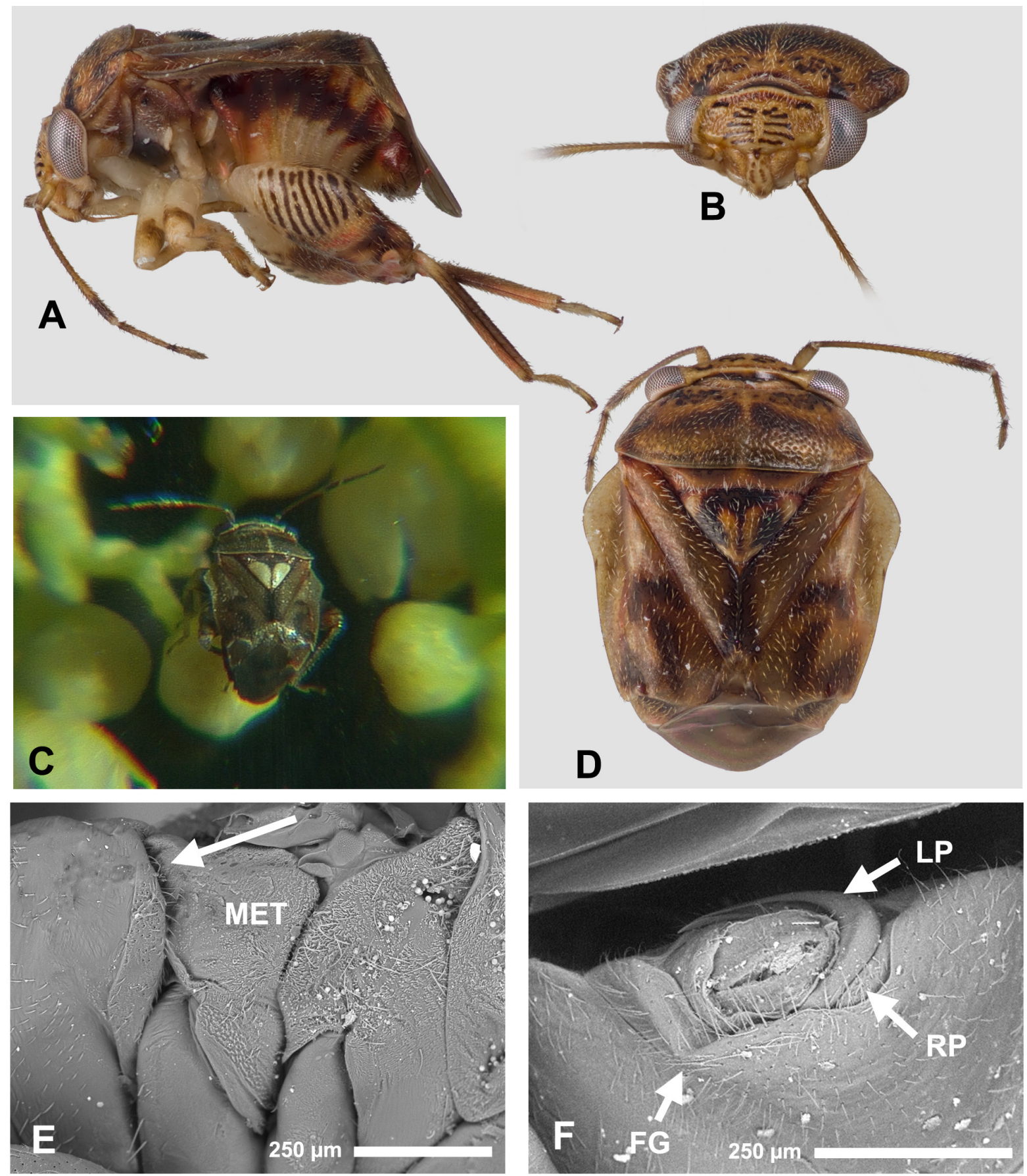

Fig. 5. Photographs and scanning electron micrographs of Coridromius norfolkensis sp. nov. A. Lateral view, ठ․ B. Head and pronotum, anterior view, ठ․ C. Photograph of C. norfolkensis sp. nov. (sex unknown) on Schinus terebinthifolius, showing alternate scutellum colouration. D. Dorsal habitus, $\widehat{O}$. E. Metathorax and anterior of abdomen, lateral view, + , arrow indicates site of insemination. F. $\hat{\delta}$ genitalia, posterior view. $\mathrm{FG}=$ folded groove of pygophore, $\mathrm{LP}=$ left paramere, $\mathrm{MET}=$ metepimeral lobe, $\mathrm{RP}=$ right paramere. 
Colouration (Fig. 5A-D). Mostly pale brown with cream and darker brown markings. Head: Mostly brownish-yellow with dark brown vittae on frons, posterior of head with transverse orange-brown marking, inner ocular margins and posterior margin of vertex cream, paired minor swellings on vertex white, bordered posteriorly with dark brown transverse markings (Fig. 5B). Clypeus cream coloured, basally with median irregular dark brown spot, laterally and apically with irregular brown markings, mandibular and maxillary plates pale (Fig. 5B). Buccula cream, basally brown, labrum cream (Fig. 5A). Labium cream, brown apically. Antennae: AI pale yellow-brown with or without faint, thin brown apical annulation, AII orange-brown, dark brown at apex, AIII and AIV orange-brown, slightly darker at base (Fig. 5A-B, D). Thorax: Pronotal collar yellow-brown with darker brown anterior and posterior margins (Fig. 5B, D). Pronotum orange-brown, medially with faint, pale midline, anteriorly with transverse field of dark brown spots either side of midline, medially with paired transverse brown markings, tapering towards lateral margins, faintly browned at humeral angles and along posteromedial margin (Fig. 5BD). Mesoscutum orange-brown with broad, paired black triangular markings on either side of midline (Fig. 5D). Scutellum orange-brown with black midline narrowing to apex, basally and laterally with dark brown to black spots, basal corners orange-brown, bordered posteriorly by faint cream markings, apically cream (Fig. 5D); in some specimens with prominent paired cream apical markings to either side of midline, occupying much of scutellum (Fig. 5C). Propleuron orange-brown with yellowed posterior margin (Fig. 5A). Mesopleuron orange-brown dorsally, becoming black ventrally, yellowed along posterodorsal margin and adjacent to mesocoxa (Fig. 5A). Metepimeron mostly orange-brown, yellowed along peritreme (Fig. 5A). Hemelytra: Mostly orange-brown. Claval commissure dark brown, corium with transverse brown markings medially and vertical brown markings caudally, apex of embolium brown, cuneus dark brown basally, orange-brown towards apex, membrane pale brown with darker veins (Fig. 5C-D). Legs: Coxae cream (Fig. 5A). Pro- and mesofemora cream with faint to pronounced, subapical brown band, metafemur cream basally, with nine contrasting dark brown stripes on outer surface bordered apically with faintly reddened patch, becoming brown towards ventral surface, apically mostly dark brown, with faintly reddened subapical lateral sulcus (Fig. 5A). Pro- and mesotibiae cream basally, quickly becoming darker brown, slightly orange or red towards apex. Metatibia pale orangebrown to darker chocolate brown, pale basally (Fig. 5A). Tarsi cream, brown apically. Abdomen: Mostly cream, males with dorsolateral margin with broad brown band, becoming reddened towards apex, anterolateral margin adjacent to metathorax often darkest brown (Fig. 5A).

Surface And vestiture (Fig. 5A-F). Head glossy and shallowly punctate (Fig. 5B), pronotum and scutellum shallowly punctate (Fig. 5D), propleuron, metepimeron, and hemelytra impunctate (Fig. 5DE). Head with sparse distribution of short, white setae (Fig. 5B). Pronotal collar with semierect short white setae. Pronotum, thoracic pleura, abdomen and legs with short, white, decumbent setae. Caudally directed spines of metatibia short and thin (Fig. 5A).

HEAD. Approximately $6.8 \mathrm{x}$ as wide as eye (Fig. 5B) in anterior view. Frons weakly convex with paired minute tumescences adjacent to eyes, bordered posteriorly by shallow, transverse sulcus (Fig. 5B). When viewed from front posterior margin of head slightly rounded medially but otherwise flat (Fig. 5B).

THorax. Pronotum broad and weakly rounded, lateral margins thinly carinate, posterior margin almost straight, weakly medially cleft, submarginal region of humeral angles weakly excavate (Fig. 5D). Proepimeron unilobed (Fig. 5A). Posterior margin of metepimeron curved inwards, closely adpressed to and partially obscured by abdomen (Fig. 5E). Scutellum weakly swollen (Fig. 5D).

HemelytRa. Embolium thin, anterolateral margin distinctly flared (Fig. 5D).

Legs. Metafemora incrassate, metatibia rectilinear, paired row of caudally directed spines thin and short (Fig. 5A). 
AвDOMEN. In female anterolateral margins slightly swollen, particularly on right. Posterior margin of abdominal sternite II mostly vertical, not sharply angular (Fig. 5E) in lateral view.

MALE GENITALIA. Right paramere triangular and weakly convex on inner surface, left paramere sickleshaped, groove to accommodate aedeagus open the entire length (Fig. 5F). Posterior margin of pygophore biconvex, with shallow folded groove left of centre (Fig. 5F).

Female paragenitalia. Paragenital guide formed by faint groove on surface of recurved right metepimeron and shallow (Fig. 5E), weakly sclerotized depression on anterolateral margin of abdomen; mating scars sometimes visible in dissected specimens.

\section{Hosts}

Presently known only from the invasive weed Schinus terebinthifolius (Fig. 5C), but thought to be originally associated with one of the several species of Euphorbiaceae native to the island.

\section{Distribution}

Restricted to Norfolk Island.

\section{Remarks}

On a recent trip to Norfolk Island, C. norfolkensis sp. nov. was found in large numbers on the introduced weed Schinus terebinthifolius, known as Brazilian pepper (Anacardiaceae: also called Hawaiian holly). This weedy invasive was first introduced to Norfolk Island in the 1920s, and has now spread throughout the island (Margaret Christian, pers. comm.). A native of South America, it is also a pest in Hawaii, Florida, New Caledonia, Fiji, Tahiti, and Mauritius (Meyer 2000). It is worth noting that the recently discovered species C. taravao sp. nov. from Tahiti (described below) has also been found in large numbers on Brazilian pepper, which is also an invasive weed in French Polynesia. Ironically, while native habitat has been severely degraded by human settlement in both of these oceanic islands, this human introduced weed may end up providing a viable habitat for these and other endemic species.

C. norfolkensis sp. nov. is the only Australian species known to exhibit visible external female paragenitalia. In other Australian endemic species (C. chenopoderis Tatarnic \& Cassis, 2008; C. monotocopsis Tatarnic \& Cassis, 2008; C. pilbarensis Tatarnic \& Cassis, 2008), females exhibit no discernable paragenital modifications, and mating scars are seldom visible.

\section{Coridromius tafo sp. nov.}

Fig. 6A-C

urn:Isid:zoobank.org:act:D6FA1755-BA24-4167-8F89-DCD8A979107C

\section{Diagnosis}

Distinguished by the following combination of characters: pronotum with anterior margin steeply declivent and posterior margin cleft, left paramere evenly curved, gutter of left paramere nearly enclosed its entire length, and ventral apical process of pygophore broad.

\section{Etymology}

Named after Tafo, the type locality.

\section{Type material}

\section{Holotype}

O, GHANA: Ashanti, Tafo, $6.7333^{\circ} \mathrm{N}-1.6167^{\circ} \mathrm{W}, 278 \mathrm{~m}, 1$ Oct. 1965, D. Leston (AMNH_PBI 00192803) (BMNH). 


\section{Description}

Body Length. $\lesssim$ (holotype): 1.71.

Colouration (Fig. 6A-B). Mostly orange-brown with yellow-brown markings. Head: Concolourous brown, frons without vittae, medial margin of eyes and posterior margin of head with faint yellow piping, clypeus darker brown (Fig. 6B). Antennae: AI brown, apically yellow, AII basal half pale orange-brown, apical club dark brown with narrow while annulation at base, AIII and AIV dark brown, basally pale (Fig. 6A). Thorax: mostly orange-brown. Pronotum orange-brown, slightly paler apically, with faint pale midline stripe (Fig. 6A-B). Scutellum orange-brown with pale apical fascia (Fig. 6A). Thoracic pleura orange brown, apices of proepimeron pale, mesepisternum darker ventrally, metathoracic scent gland peritreme pale. Hemelytra: brown, slightly paler towards costal margin, cream coloured at cuneal fracture (Fig. 6A). Cuneus with large, irregular dark brown marking, laterally with faint reddish flecking, apically pale, membrane brown. Abdomen: orange-brown, with small, very faint darker brown markings along dorsolateral margin. Legs: coxae dark brown, apically pale. Pro- and mesofemora brown, somewhat paler apically, metafemur with dark brown banding on lateral surface, fusing dorsally, subapically with pale mark dorsally, subapical bothria pale; tibiae yellow to pale orange brown, with irregular dark brown subbasal annulation.

SuRface And vestiture (Fig. 6A-B). Head with a few irregular punctures medially on vertex. Pronotum, scutellum, and propleuron punctate, hemelytron with punctures basally, becoming smooth on corium

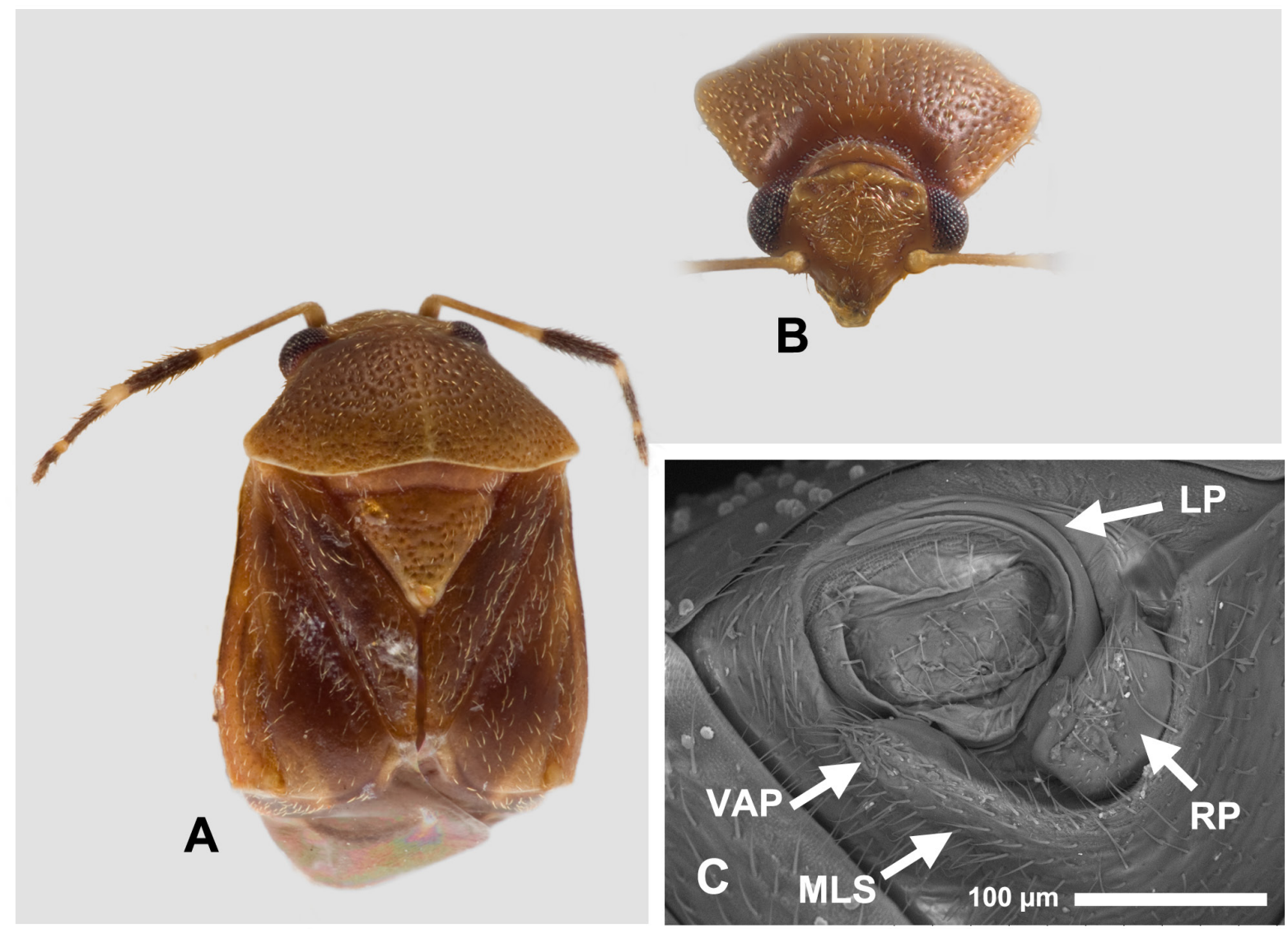

Fig. 6. Photographs and scanning electron micrograph of Coridromius tafo sp. nov. A. Dorsal habitus. B. Head and pronotum, anterior view. C. $\delta$ genitalia. LP = left paramere, MLS = mesal longitudinal suture of pygophore, $\mathrm{RP}=$ right paramere, $\mathrm{VAP}=$ ventral apical process. 
(Fig. 6A). Body with sparse coating of short, thin, hairlike setae. Head with sparse coating of very short adpressed setae, gena with a few longer semierect setae. Antennae clothed in semi-erect setae interspersed with more erect, thin spinelike setae (Fig. 6A). Pronotum with sparse distribution of very short, reclining setae; hemelytra with sparse distribution of short, semi-reclining setae (Fig. 6A). Thoracic pleura with a few hairlike setae, abdomen with slightly more dense coating of longer, semi-erect setae. Femora with semi-erect setae, metafemoral apical bothrial setae long. Tibiae with semi-erect setae, metatibia with two rows of thick, caudally directed spines.

HEAD. Approximately $5.8 \mathrm{x}$ as wide as eye (Fig. 6B) in anterior view. Frons weakly tumescent; vertex with transverse depressions adjacent to eyes, posterior margin broadly medially rounded, not carinate (Fig. 6B). Buccula swollen.

ANTENNAE. AII basally thin, apically clavate.

Thorax. Pronotal collar broad and rounded (Fig. 6B). Pronotum broad, broadly tumescent medially, anterior margin steeply declivent, callosite region undifferentiated, posterior of humeral angles distinctly depressed, posterior margin carinate and medially concave (Fig. 6A-B). Proepimeron bilobed. Posterior margin of metepimeron truncate. Surface of scutellum flat, apex broadly rounded (Fig. 6A).

Hemelytra. Costal margin thinly carinate, weakly flared posteriorly (Fig. 6A).

ABDOMEN. When viewed laterally, posterior margin of abdominal sternite II not distinctly angular.

Male genitalia. Posterior margin of pygophore with broad, fingerlike ventral apical apophysis, mesal longitudinal suture long (Fig. 6C). Left paramere shorter than in many other species ( $2 \mathrm{x}$ right paramere length), extremely thin and evenly curved, gutter enclosing aedeagus nearly enclosed its entire length, right paramere broad and subtriangular (Fig. 6C).

Female Paragenitalia. Unknown.

\section{Host}

No host records.

\section{Distribution}

Known only from Tafo, Ghana.

\section{Remarks}

In 1974, Linnavuori described C. schuhi from a single specimen collected on Mount Tonkoui, Ivory Coast (Linnavuori 1994). Unfortunately, the sole specimen of this species appears to have been lost (Tatarnic \& Cassis 2008), and its description lacks sufficient detail to determine whether or not it is conspecific with $C$. tafo sp. nov. Though the described colouration of $C$. schuhi differs from that of the sole specimen of C. tafo sp. nov. (the former being much darker), other species of Coridromius are highly variable in their colouring (e.g., C. chenopoderis Tatarnic \& Cassis, 2008; C. zetteli Chérot, Konstantinov \& Yasunaga, 2004: see Tatarnic \& Cassis 2010), and without a larger sample size we cannot ascertain the degree of colour variation across these species. We therefore take the conservative approach in designating $C$. tafo sp. nov. a distinct species. 


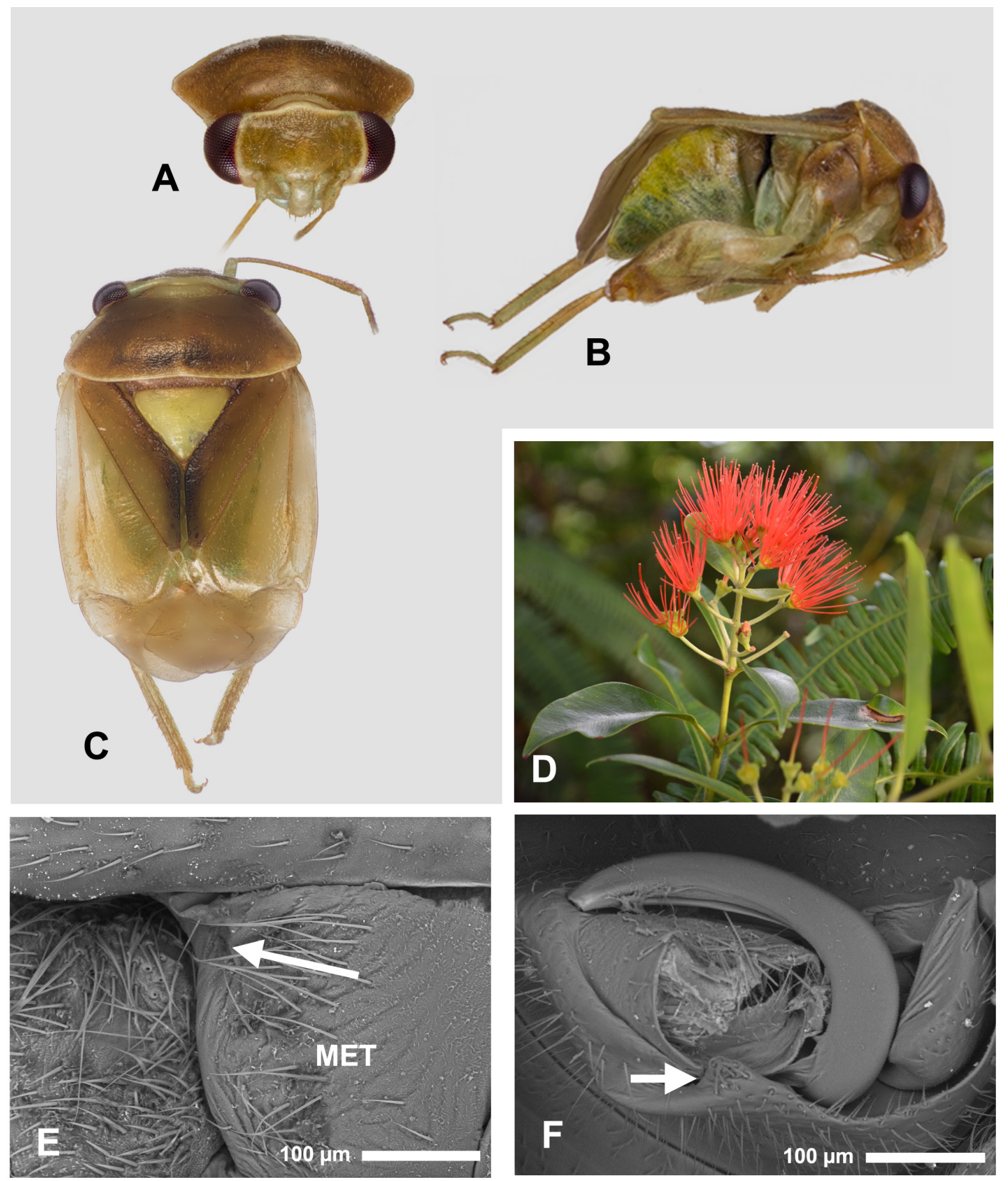

Fig. 7. Photographs and scanning electron micrographs of Coridromius taravao sp. nov. and Metrosideros collina. A. Head and pronotum, anterior view. B. Right lateral view, $q$. C. Dorsal habitus, ${ }^{\prime}$. D. Photograph of Metrosideros collina at Taravao Plateau. E. Detail of metepimeral lobe and anterior of abdomen; arrow indicates possible site of insemination. F. Ô genitalia, apex of left paramere broken off; arrow indicates apophysis of pygophore margin. MET = metapimeral lobe. 


\section{Coridromius taravao sp. nov. \\ Fig. 7A-F \\ urn:1sid:zoobank.org:act:CA3A80CD-C062-4F64-A5B4-FECA0B2100C5}

\section{Diagnosis}

Distinguished by the following combination of characters: relatively small size, overall pale green/brown colour with matte yellow scutellum, frons without vittae, and brown diagonal stripes on metafemur faint or absent, and females with right anterior abdominal laterosternite slightly swollen, blackened and heavily sclerotized.

\section{Etymology}

\section{Type material}

\section{Holotype}

${ }^{7}$, FRENCH POLYNESIA, Society Islands, Tahiti Island: Tahiti Iti, Taravao Plateau, $17.77665^{\circ} \mathrm{S}-$ 149.25456 W, 877 m, 19 May 2011, G. Cassis \& N. Tatarnic, Metrosideros collina (Myrtaceae), det. Jean-Yves Meyer (UNSW_ENT 00000028) (MNHN).

\section{Paratypes}

FRENCH POLYNESIA, Society Islands, Tahiti Island: Tahiti Iti, Taravao Plateau, $17.77665^{\circ} \mathrm{S}-$ 149.25456 W, 877 m, 19 May 2011, G. Cassis \& N. Tatarnic, Metrosideros collina (Myrtaceae), det. Jean-Yves Meyer, 1 ○ (UNSW_ENT 00046011), 1 \& (UNSW_ENT 00046012) (BPBM); Metrosideros collina (Myrtaceae), det. Jean-Yves Meyer, 1 q (UNSW_ENT 00000029) (MNHN); Metrosideros collina, det. Jean-Yves Meyer, $1 \jmath^{\Uparrow}$ (UNSW_ENT 00000030), 3 + $q$ (UNSW_ENT 00000031-00000033) (UNSW). Tahiti Island, Tahiti Nui, Base of Belvedere Trail, Rau Ape Aorai, $17.551^{\circ} \mathrm{S}-149.529^{\circ} \mathrm{W}$, 331 m, 1-8 Apr. 2012, G. Cassis \& N. Tatarnic, Schinus terebinthifolius Raddi (Anacardiaceae), 2 ๙ (UNSW_ENT 00400051-00400052), 3 우 (UNSW_ENT 00400053-00400055) (UNSW).

\section{Description}

Body LENGTH. $\widehat{\partial}(\mathrm{n}=4): 1.97-2.75 \mathrm{~mm}$; + ( $\mathrm{n}=8): 2.05-2.76 \mathrm{~mm}$.

Colouration (Fig. 7A-C). Both sexes usually pale tan-brown with a greenish tint and conspicuous yellow scutellum; females rarely predominantly darker brown. Head: pale brown, frons without vittae, inner ocular margin and posterior margin of head pale yellow (Fig. 7A). Clypeus, mandibular and maxillary plates cream to brown (Fig. 7A). Buccula orange-brown in some specimens, in others basally yellowbrown to pale green, white along ventral margin. Labrum orange-brown. Labium cream basally, becoming brown towards apex. Antennae: mostly orange-brown. AI pale cream, AII orange-brown, Apex of AII, and AIII-AIV darker brown (Fig. 7B-C). Eyes red. Thorax: Pronotal collar cream (Fig. 7A). Pronotum pale tan-brown with irregular black markings before caudal margin in some specimens, caudal margin yellow (Fig. 7C). Scutellum matte yellow (Fig. 7C). Thoracic pleura predominantly orange-brown (Fig. 7B). Hemelytra: mostly pale orange-brown, with a faint green tint on corium, inner margin of clavus and claval commisure blackened, forming a distinctive Y-shaped pattern, membrane hyaline, veins nearly indistinguishable (Fig. 7C). Abdomen: Faintly tinted green in both sexes, in female with first visible segment on right side (paragenital region) embrowned with leading edge dark black (Fig. 7B). Legs: All coxae cream, pro- and mesofemora cream, faintly orange-brown at apex, metafemur mostly cream, sometimes with faint brown diagonal striping on outer surface, apical $1 / 4$ orange-brown (Fig. 7B). All tibiae yellow to yellow-brown, apically tinted brown or green in some specimens; tarsi pale, apically embrowned (Fig. 7B). Females almost always coloured identically to males, rare individuals are much 
darker, with dorsum predominantly darker brown, scutellum embrowned, hemelytra with faint dark brown chevron immediately above cuneus, abdomen brown and apices of femora embrowned.

Surface And vestiture (Fig. 7A-C, E). Head shallowly punctate, pronotum finely punctate, thoracic pleura, scutellum and hemelytra impunctate. Body with sparse covering of short, hairlike, decumbent setae. Both sexes with patch of elongate setae on right side of abdomen.

HeAD. Approximately $5.7 \mathrm{x}$ as wide as eye (Fig. 7A) in anterior view. Frons weakly tumescent medially, vertex with faintly raised tumescences adjacent to eyes, bordered above by shallow depressions, posterior margin of head weakly carinate, when viewed from front weakly convex medially but otherwise flat (Fig. 7A).

Thorax. Pronotum broad, weakly convex, calli ill-defined, anterolateral margins weakly upturned and carinate, submarginal regions of humeral angles weakly depressed, posterior margin carinate and weakly concave (Fig. 7A, C). Proepimeron unilobed (Fig. 7B). Posterior margin of metepimeron rounded and subtriangular, partly overlapping anterior of abdomen (Fig. 7E). Scutellum weakly rounded (Fig. 7C).

HemelYtRa. Costal margin flared its entire length, straight to weakly sinuate (Fig. 7C).

Legs. Metatibial spines short and thin (Fig. 7B). Abdomen: Posterior margin of abdominal sternite II (first visible sternite) weakly convex in lateral view, females with anterior margin on right side heavily sclerotized and swollen (Fig. 7B).

MaLe Genitalia. Posterior margin of pygophore with folded groove to right of centre, right margin of groove with small, triangular apophysis (Fig. 7F). Left paramere approximately $2.5 \mathrm{x}$ length of right paramere, evenly curved with gutter accommodating aedeagus open its entire length, right paramere broad and subtriangular (Fig. 7F).

Female PaRagenitalia. Anterior of right abdominal sternite II (first visible abdominal sternite) weakly swollen and heavily sclerotized; posterior margin of metepimeral lobe deflected inward and interlocking on right side with anterior swelling of sternite II (Fig. 7B, E). Female site of insemination unknown, thought to be stabbed either along anterior or abdomen adjacent to metacoxa, concealed by metepimeral lobe, or possibly on the other side of the abdomen, in a shallow depression behind the metepimeral lobe.

\section{Hosts}

Collected from Metrosideros collina (J.R. Forst \& G. Forst) A. Gray, 1854 (Myrtaceae) (Fig. 7D) and Schinus terebinthifolius (Anacardiaceae).

\section{Distribution}

Presently known only from Taravao Plateau and the base of the Belvedere Trail, Rau Ape Aorai, Tahiti Island.

\section{Remarks}

The new species was collected, along with the superficially similar C. tahitiensis Tatarnic \& Cassis, 2008, at the same two localities and from the same host plants. All but a few female C. taravao sp. nov. share the same colouration as male $C$. tahitiensis, and are often difficult to identify without careful examination of the metepimeral lobe (deflected inwards in C. taravao sp. nov., extended caudally in C. tahitiensis) and the female paragenitalia (in C. taravao sp. nov. as described above, in C. tahitiensis manifested as a large invaginated copulatory sinus between abdominal sternites II and III). 


\section{Discussion}

Coridromius species exhibit a Wallacean distribution, with distinct, phylogeneticlly supported eastern and western species groups (Tatarnic \& Cassis 2010). Species in the eastern group are most easily recognized by their unilobate proepimeron, as well as the generally triangular shape of the right paramere, while those of the western group exhibit a bilobed proepimeron and the right paramere is usually (though not always) club-shaped with a thumb- or spinelike apophysis. The species described herein mostly conform to this trend: the "western species" C. basilanus sp. nov., C. eremnos sp. nov., C. fomangsu sp. nov., C. mulu sp. nov., and C. tafo sp. nov. all display a bilobed proepimeron and (in those species where the male is known) a western type right paramere, whereas the eastern species C. norfolkensis sp. nov. and C. taravao sp. nov. have a unilobed proepimeron and triangular right paramere. This distinction is not perfect however, with the Mauritian species C. macchabeeus sp. nov. displaying a proepimeron that is apparently intermediate between the two types. At first glance the proepimeron appears unilobed, but closer inspection reveals a reduced anterior lobe that is partly obscured by the posterior lobe and the eye (Fig. 3C). Similarly, the right paramere of C. fomangsu sp. nov. from Ghana bears a unique apophysis unseen in other Coridromius. We suspect that further collecting in Africa will yield additional new species, possibly bearing similar morphological departures from the norm. Until we achieve greater representation of African species, we cannot yet say whether these will form one or several subclades distinct from the more thoroughly represented Southeast Asian and Austral Pacific species.

Coridromius was originally considered rare in collections (Schuh 1974), and until quite recently was only known from 10 species. With a recent revision of the genus (Tatarnic \& Cassis 2008) the number of described species was extended to 33, and in the present paper we add an additional eight. We anticipate that with further, targeted collecting in undersampled regions - particularly in Africa and Southeast Asia - many new species remain to be discovered.

\section{Acknowledgements}

We wish to thank the following people: Chris Darling (ROM) for facilitating fieldwork in Sarawak; Anna Namyatova (UNSW) for assistance collecting C. norfolkensis sp. nov. in Norfolk Island; Margaret Christian for facilitating our Norfolk Island field research as well as for sharing her in-depth knowledge of the island's flora; and Jean-Yves Meyer (Délégation a la Recherche, Tahiti) for assistance with fieldwork and plant identification in Tahiti. For the loan of specimens we thank: Dave Britton, Australian Museum, Sydney; Randall Schuh, American Museum of Natural History, New York; David Yeates, Australian National Insect Collection, CSIRO, Canaberra; Mick Webb, British Museum, London; Shepherd Myers, Bernice P. Bishop Museum, Honolulu; and Tom Henry, United States National Museum of Natural History, Smithsonian Institution, Washington. This research was funded through a grant from the Australia \& Pacific Science Foundation to N. J. Tatarnic and G. Cassis (APSF 08/5), as well as an NSF Planetary Biodiversity Inventories Grant to R. T. Schuh and G. Cassis (DEB-0316495).

\section{References}

Carayon J. 1966. Paragenital system. In: R. Usinger (ed) Monograph of the Cimicidae: 81-167. Entomological Society of America, Philadelphia.

Carpintero D.L. \& Guarda P.J. 2011. Coridromius chenopoderis Tatarnic \& Cassis, 2008: a new introduced Miridae (Hemiptera: Heteroptera) in Chilean fauna. Boletin de Biodiversidad de Chile 5: $22-27$.

Cassis G. \& Gross G.F. 1995. Hemiptera: Heteroptera (Coleorrhyncha to Cimicomorpha). In: Houston W.W.K. \& Maynard G.V. (eds) Zoological Catalogue of Australia. Vol 27.3A, CSIRO, Melbourne. 
Linnavuori R.E. 1994. Orthotylinae of West, Central and North-East Africa (Heteroptera, Miridae). Acta Zoologica Fennica 193: 1-84.

Meyer J.Y. 2000. Preliminary review of the invasive plants in the Pacific Islands (SPREP Member Countries). In: Sherley G. (ed.) Invasive species in the Pacific: a technical review and draft regional strategy: 85-115. South Pacific Regional Environment Programme, Samoa.

Montrouzier P. 1861. Essai sur la faune entomologique de la Nouvelle-Calédonie (Balade) et des Iles des Pins, Art, Lifu, etc. Hémiptères. Annales de la Société Entomologique de France 1: 59-74.

Morrow E. \& Arnqvist G. 2003. Costly traumatic insemination and a female counter-adaptation in bed bugs. Proceedings of the Royal Society B: Biological Sciences 270: 2377-2381. http://dx.doi. org/10.1098/rspb.2003.2514

Reinhardt K., Naylor R. \& Siva-Jothy M. 2003. Reducing a cost of traumatic insemination: female bedbugs evolve a unique organ. Proceedings of the Royal Society of London, B: Biological Sciences 270: 2371-2375. http://dx.doi.org/10.1098/rspb.2003.2515

Schuh R.T. 1974. The Orthotylinae and Phylinae (Hemiptera: Miridae) of South Africa with a phylogenetic analysis of the ant-mimetic tribes of the two subfamilies for the world ( 2 of 5). Entomologica Americana 47: 1-332.

Schuh R.T. 1975. Plant Bugs of the World (Insecta: Heteroptera: Miridae). Systematic Catalog, Distributions, Host List, and Bibliography. NewYork Entomological Society, New York.

Siva-Jothy M.T. 2006. Trauma, disease and collateral damage: conflict in cimicids. Philosophical Transactions: Biological Sciences 361: 269-275. http://dx.doi.org/10.1098/rstb.2005.1789

Tatarnic N.J. \& Cassis G. 2008. Revision of the plant bug genus Coridromius Signoret (Insecta: Heteroptera: Miridae). Bulletin of the American Museum of Natural History 315: 1-95. http://dx.doi. org/10.1206/315.1

Tatarnic, N.J. \& Cassis, G. 2010. Sexual coevolution in the traumatically inseminating plant bug Coridromius. Journal of Evolutionary Biology 23: 1321-1326. http://dx.doi.org/10.1111/j.14209101.2010.01991.x

Tatarnic N.J. \& Cassis G. 2012. The Halticini of the world (Insecta: Heteroptera: Miridae: Orthotylinae): generic reclassification, phylogeny, and host plant associations. Zoological Journal of the Linnean Society 164: 558-658. http://dx.doi.org/10.1111/j.1096-3642.2011.00770.x

Tatarnic N.J., Cassis G. \& Hochuli D. 2006. Traumatic insemination in the plant bug genus Coridromius Signoret (Heteroptera: Miridae). Biology Letters 2: 58-61. http://dx.doi.org/10.1098/rsbl.2005.0394

Manuscript received: 4 October 2012

Manuscript accepted: 7 January 2013

Published on: 28 January 2013

Topic editor: Koen Martens

Printed versions of all papers are also deposited in the libraries of the institutes that are members of the EJT consortium: Muséum National d'Histoire Naturelle, Paris, France; National Botanic Garden of Belgium, Meise, Belgium; Royal Museum for Central Africa, Tervuren, Belgium; Natural History Museum, London, United Kingdom; Royal Belgian Institute of Natural Sciences, Brussels, Belgium; Natural History Museum of Denmark, Copenhagen, Denmark. 